\title{
EXPRESS VERSUS AUTOMATIC ASSIGNMENT OF SECTION 10(b) CAUSES OF ACTION
}

In Lowry v. Baltimore \& Ohio Railroad, ${ }^{1}$ the United States Court of Appeals for the Third Circuit considered whether the owner of a security may assert his seller's section 10(b) cause of action if the current owner did not receive an express assignment of the seller's rights. ${ }^{2}$ That is, if the seller of a security has a section 10(b) claim, does the seller's cause of action "run with the security" so that the seller's purchaser takes the seller's cause of action by automatic assignment, or must the purchaser secure an express assignment of the seller's cause of action in order for the purchaser to sue the party who defrauded the seller?

This note addresses the issue whether a section 10(b) cause of action should run with the security where existence of the cause of action has become a matter of public knowledge. The note first reviews the law of assignments of causes of action in general, ${ }^{3}$ and then summarizes three possible resolutions of the issue: adopting a rule of automatic assignments, ${ }^{4}$ inferring the parties' intent from the facts, ${ }^{5}$ and requiring an expression of the parties' intent. ${ }^{6}$ In discussing these three resolutions, the note evaluates the various arguments expressed in Lowry, ${ }^{7}$ the consistency of each argument with the law of assignments ${ }^{8}$ and with federal securities law, ${ }^{9}$ and the ramifications of each argument for maintaining class actions. ${ }^{10}$ The note concludes that an express assignment of the

1. 707 F.2d 721 (3d Cir.) (en banc), modification denied, 711 F.2d 1207 (3d Cir.), cert. denied, 104 S. Ct. 238 (1983).

2. The cause of action need not be against the seller's seller. The claim may be against any party employing a fraudulent or manipulative device within the meaning of section 10(b) of the Securities Exchange Act of 1934, 15 U.S.C. \$ 78j(b) (1982). That section provides:

It shall be unlawful for any person, directly or indirectly, by the use of any means or instrumentality of interstate commerce or of the mails, or of any facility of any national securities exchange...

(b) To use or employ, in connection with the purchase or sale of any security registered on a national securities exchange or any security not so registered, any manipulative or deceptive device or contrivance in contravention of such rules and regulations as the Commission may prescribe as necessary or appropriate in the public interest or for the protection of investors.

3. See infra notes $22-51$ and accompanying text.

4. See infra notes $52-60$ and accompanying text.

5. See infra notes $61-62$ and accompanying text.

6. See infra notes 63-66 and accompanying text.

7. See infra notes 71-93 and accompanying text.

8. See infra notes $94-99$ and accompanying text.

9. See infra notes 100-10 and accompanying text.

10. See infra notes $80-88,114-15$ and accompanying text. 
seller's cause of action should be required in order to effect an assignment, at least where the fraud was public information when the security was transferred. ${ }^{11}$ Under this approach, the cause of action is not assigned automatically to the purchaser by the mere resale of the security.

\section{LOWRY V. BALTIMORE \& OHIO RAILROAD}

In Lowry, the Baltimore \& Ohio Railroad Company (B\&O) owned both rail and nonrail assets and had outstanding common stock and convertible debentures. ${ }^{12}$ In order to avoid federal regulation of its nonrail assets, B\&O created a subsidiary, Mid-Allegheny Corporation (MAC). ${ }^{13}$ B\&O transferred its nonrail assets to MAC, and on December 13, 1977, $\mathrm{B} \& \mathrm{O}$ declared and distributed to its common shareholders a dividend in the form of MAC stock. ${ }^{14}$ In concurrently declaring and distributing the dividend, $\mathrm{B} \& \mathrm{O}$ wrongfully prevented holders of its convertible debentures from exercising their conversion option in time to participate in the distribution. ${ }^{15}$ Holders of record of the debentures as of December 13, 1977, prevailed against B\&O under section $10(\mathrm{~b})$ and Rule 10b-516 in Pittsburgh Terminal Corp. v. Baltimore \& Ohio Railroad. ${ }^{17}$

The plaintiffs in Lowry purchased their debentures from persons holding them on December 13,1977, and sought to maintain their sellers' section 10(b) causes of action by claiming that their purchase of the debentures effected an automatic assignment of the sellers' claims against B\&O. ${ }^{18}$ Lowry thus presents the question whether a section 10(b) cause of action runs with the security or whether an express assignment of the cause of action is required in order for the purchaser to sue as assignee of the seller's claims.

11. See infra note 91 .

12. Lowry, 707 F.2d at 722.

13. Id.

14. Id.

15. Id.; Pittsburgh Terminal Corp. v. Baltimore \& O.R.R., 680 F.2d 933, 942 (3d Cir.) (holding B\&O liable under section 10(b) and Rule 10b-5), cert. denied, $103 \mathrm{~S}$. Ct. 476 (1982). The deprivation of timely notice needed by debenture holders to exercise their conversion option came within the 10(b) prohibition against use of manipulative devices "in connection with the purchase or sale of any security," 15 U.S.C. $\S 78 \mathrm{j}(\mathrm{b})$ (1982), because "a contract to buy or sell securities is a purchase or sale within the meaning of section 10(b)." Pittsburgh Terminal, 680 F.2d at 940 . The conversion option in a convertible debenture is a contract to buy or sell securities and hence "qualifies as a contract for the purchase or sale of a security." Id.

16. 17 C.F.R. $\S 240.10 b-5$ (1980).

17. Pittsburgh Terminal, 680 F.2d at 943. The parties in Pittsburgh Terminal stipulated that any judgment in favor of the plaintiffs would inure to the benefit of bondholders situated similarly to the plaintiffs. Id. at 939. See also Pittsburgh Terminal Corp. v. Baltimore \& O.R.R., 509 F. Supp. 1002, 1009 (W.D. Pa. 1981), aff'd in part and rev'd in part, 680 F.2d 933 (3d Cir.), cert. denied, 103 S. Ct. 476 (1982).

18. Lowry, 707 F.2d at 721. 
Reviewing the district court's dismissal of the complaint in Lowry, the eight-member panel of the Third Circuit split three ways. Two judges approved of the district court's dismissal on the ground that the appellants' predecessors in title had no causes of action to assign; thus, they did not reach the issue of automatic assignment. ${ }^{19}$ A plurality of three judges believed that the appellants could not assert the sellers' section 10(b) claims because the sellers had not expressly assigned their causes of action to the appellants. ${ }^{20}$ Thus, five judges voted to affirm. The three dissenters argued that the sellers' section 10(b) claims ran with the securities automatically upon sale, and hence that the appellants could sue as the sellers' assignees without an express assignment to that effect. ${ }^{21}$ The judges who reached the question of automatic assignment were therefore evenly divided.

\section{Assignment of Causes of Action}

\section{A. Assignability of Causes of Action at Common Law.}

"An assignment in law is a transfer or setting over of property, or some right or interest therein."22 Use of the term "assignment" is ordinarily limited to the transfer of rights incident to property, as distinguished from the particular chattel itself, and to the transfer of what are commonly referred to as "choses in action." 23 A chose in action literally is a "thing in action." 24 More precisely, a chose in action is "a personal right not reduced into possession, but recoverable by a suit at law."25 The concept properly encompasses both the property and the right of action $^{26}$ associated with it, ${ }^{27}$ but the term "chose in action" is sometimes

19. Id. at 732 (Aldisert, J., joined by Hunter, J., concurring in part and dissenting in part).

20. Id. at 729, 732 (Garth, J., joined by Sloviter, J., concurring); id. at 731, 732 (Adams, J., concurring).

21. Id. at 734, 739-41 (Gibbons, J., dissenting); id. at 744, 746-47 (Seitz, C.J., joined by Becker, $\mathrm{J}$. , concurring in part and dissenting in part).

22. In re Beffa's Estate, 54 Cal. App. 186, 189, 201 P. 616, 617 (1921); see In re Bradley, 17 Bankr. 107, 110 (Bankr. M.D. Tenn. 1981) (“An assignment is a transfer of property, right or interest from one person to another.").

23. In re Beffa's Estate, 54 Cal. App. 186, 189, 201 P. 616, 617 (1921).

24. Peavy Lumber Co. v. Murchison, 272 Ala. 251, 253, 130 So. 2d 338, 340 (1961) ("A thing in action is properiy distinguished from a thing of which the owner has the actual or constructive possession, but for which an action may be brought to reduce it to possession.").

25. Id. at 253,130 So. $2 d$ at 341 (quoting 42 AM. JuR. Property $\S 26$ (1942)).

26. "A right of action . . . is a right presently to enforce a cause of action by suit." McMahon v. United States, 186 F.2d 227, 230 (3d Cir. 1950), aff'd, 342 U.S. 25 (1951). A cause of action is the set of operative facts giving rise to a right of action and affording a party a right to institute a judicial proceeding. See id.; see also Whitfield v. Aetna Ins. Co., 205 U.S. 489, 496 (1907) (a cause of action is the reverse of a defense, which is defined as "[w]hatever tends to diminish the plaintiff's cause of action or to defeat recovery in whole or in part"). Although, strictly speaking, the terms "right of action" and "cause of action" have different meanings, see Reading Co. v. Koons, 271 U.S. 58, 59-60 
used to refer solely to the right of bringing an action. ${ }^{28}$ Under early common law most choses in action were not assignable absent the debtor's assent to the assignment and new promise to pay the assignee. ${ }^{29}$ Courts of equity later began to enforce bona fide assignments ${ }^{30}$ made for consideration. ${ }^{31}$

Today, a chose in action is freely assignable if the right to sue would survive the death of its owner and pass to the decedent's legal representatives. $^{32}$ In general, if a right to sue is penal ${ }^{33}$ or personal ${ }^{34}$ in nature, it

(1926), they are used synonymously in the context of survival of actions. Periard v. Nelson, $14 \mathrm{III}$. App. 2d 566, 571-72, 145 N.E.2d 172, 175 (1957).

27. Peavy Lumber Co. v. Murchison, 272 Ala. 251, 253-54, 130 So. 2d 338, 341 (1961). For example, reference to a debt as a chose in action means not only the thing itself-the debt-but also the right to recover on the debt by jndicial action. See Mexican Nat'l R.R. v. Davidson, 157 U.S. 201, 206 (1895); Young v. Garred, 90 W. Va. 767, 773, 112 S.E. 181, 184 (1922) (chose in action includes "the thing itself and . . . the right of action as annexed to it" (quoting BrAck's LAW DICTIONARY 198 (2d ed. 1910))).

28. Young v. Garred, 90 W. Va. 767, 773, 112 S.E. 181, 184 (1922).

29. See, eg., Tiernan v. Jackson, 30 U.S. (5 Pet.) 580, 601 (1831). For various grounds on which to prohibit assignments of choses in action, see Rice v. Stone, 83 Mass. (1 Allen) 566, 569 (1861) (one cannot assign that which he does not possess), Garford Motor Truck Co. v. Buckson, 34 Del. 103, 106, 143 A. 410, 411 (1927) (allowing assignment of cause of action would encourage litigiousness and violate rule against champerty and maintenance), and Atlantic \& N.C.R.R. v. Atlantic \& N.C. Co., 147 N.C. $368,374,61$ S.E. 185, 187 (1908) (choses in action are strictly personal obligations).

30. The assignments by equity courts were "equitable assignments"; courts of law continued to adhere to the early common law rule prohibiting assignments. See Little v. City of Portland, 26 Or. 235, 242, 37 P. 911,912 (1894).

31. Garford Motor Truck Co. v. Buckson, 34 Del. 103, 106-07, 143 A. 410, 411 (1927); Atlantic \& N.C.R.R. v. Atlantic \& N.C. Co., 147 N.C. 368, 374, 61 S.E. 185, 187 (1908); Little v. City of Portland, 26 Or. 235, 242-43, 37 P. 911,912 (1894). The equity courts' departure froin the ancient common law rule resulted from the perceived needs of a commercial era. As trading increased and business methods advanced, the nced for more transferable property increased along with the dcmand for private credit. The equitable assignment facilitated this growth of commerce. See Little, 26 Or. at 242,37 P. at 912.

32. See Rowe v. United States Fidelity \& Guar. Co., 421 F.2d 937, $940-42$ (4th Cir. 1970); Western Auto Snpply Co. v. Gamble-Skogmo, Inc., 348 F.2d 736, 741 (8th Cir. 1965), cert. denied, 382 U.S. 987 (1966); In re Penn Cent. Transp. Co., 337 F. Supp. 791, 794 (E.D. Pa. 1972); Mills v. Sarjem Corp., 133 F. Supp. 753, 761 (D.N.J. 1955).

The rule of survivability is soinetimes stated as follows: Most causes of action arising out of a contract survive while those founded on tort abate, subject to the exception for tort injury to property as opposed to tort injury to the individual. Barnes Coal Corp. v. Retail Coal Merchants Ass'n, 128 F.2d 645, 649 (4th Cir. 1942).

Barnes Coal Corp., 128 F.2d at 649, states the rule's rationale with respect to survival:

Underlying the distinction between actions that die with the person and those that survive is the basic thought that the reason for redressing purely personal wrongs ceases to exist either when the person injured cannot be benefited by a recovery or the person inflicting the injury cannot be punished, whereas, since the property or estate of the injured person passes to his legal representatives, a cause of action for injury done to these can achieve its purpose as well after the death of the owner as before.

The same rationale would apply to assignments.

In addition to the rule of survival, pnblic policy may also play a role in determining assignability. The "assignment inust not be: (a) Contrary to the express provisions of law; (b) contrary to the 
does not survive and is therefore not assignable 35 unless a statute provides to the contrary. ${ }^{36}$ On the other hand, a cause of action to redress injury to property rights ${ }^{37}$ survives the death of the property owner and consequently may be assigned. ${ }^{38}$

policy of express law thereof, though not expressly prohibited; (c) contrary to good morals." Sherman v. Harris, 36 S.D. 50, 55, 153 N.W. 925, 926 (1915) (finding the assignment of an action for fraudulent inducement to purchase stock subscriptions not violative of any express provisions of law, policy of express law, or good morals), aff'd on rehearing, 40 S.D. 341,167 N.W. 325 (1918), overruled on other grounds, Simons v. Kidd, 73 S.D. 280, 287, 41 N.W.2d 840, 843 (1950).

33. See Porter v. Household Fin. Corp., 385 F. Supp. 336, 340 (S.D. Ohio 1974) (quoting Huntington v. Attrill, 146 U.S. 657, 667-69 (1892)). If the purpose of the act is to punish the wrongdoer rather than to compensate the victim, the act is penal in nature. Id. For a criticism of the Huntington definition of "penal," see Note, Survival of Actions Brought Under Federal Statutes, 63 Colum. L. REv. 290, 301 (1963) (Huntington definition arose in context of full faith and credit question; application of the definition in other areas has resulted in inconsistencies). See also Schreiber v. Sharpless, 110 U.S. 76, 80 (1884) (decedent's personal representatives could not sue for penalties and forfeitures available for copyright infringment); Strickland v. Sellers, 78 F. Supp. 274, 276-77 (N.D. Tex. 1948) (claim arising under Emergency Price Control Act of 1942, ch. 26, § 205(e), 56 Stat. 23, 34 , terminated by Act of July 25, 1946, ch. $671, \S 1,60$ Stat. 664 , for treble the amount of an overcharge, held penal and nonassignable).

34. In general, the following actions are personal to the victim and not assignable in the absence of a statute providing otherwise: actions for assault and battery, see In re Dodge, 9 F. Supp. 540, 542 (N.D.N.Y. 1935), libel and slander, see Los Angeles Fire \& Protective League v. Rodgers, 7 Cal. App. 3d 419, 425, 86 Cal. Rptr. 623, 626 (1970), criminal conversation, see Gerdink v. Meginnis, 73 Ind. App. 39, 43, 126 N.E. 499, 500 (1920), false arrest, see Seaman v. Mann, 114 N.J. Eq. 408, 410, 168 A. 833, 835 (1933), false imprisonment, see Mayer v. Rankin, 91 Utah 193, 203-04, 63 P.2d 611, 616 (1936), seduction, see People ex rel. Stanton v. Tioga, 19 Wend. 73, 77-78 (N.Y. Sup. Ct. 1837), malicious abuse of process, see Tomkovich v. Mistevich, 222 Mich. 425, 429, 192 N.W. 639, 640 (1923), and other torts, see Nordling v. Johnston, 205 Or. 315, 327-28, 283 P.2d 994, 1000 (1955), are personal to the victim and not assignable in the absence of a statute providing otherwise.

35. E.g., Mills v. Sarjem Corp., 133 F. Supp. 753, 761 (D.N.J. 1955) (tests of assignability and survivability are ordinarily the same).

36. In United States v. Buford, 28 U.S. (3 Pet.) 12, 30 (1830), the Supreme Court, operating under rules allowing equitable but not legal assignments, see supra notes $30-31$ and accompanying text, held a cause of action to recover a debt owed to the Treasury Department assignable to the United States by act of Congress even though the plaintiffs could claim as assignees in equity but not at law. See also Brazier v. Cherry, 293 F.2d 401, 409 (5th Cir.) (state survival statute gave rise to federally enforceable claim for damages despite death of victim of civil rights violation), cert. denied, 368 U.S. 921 (1961); Southern Ry. v. Stonewall Ins. Co., 177 Ala. 327, 333, 58 So. 313, 314 (1912) (claim for tortious injury to property assignable by statute but not otherwise under state common law).

37. For example, union membership and pension benefits constitute property rights; thus a cause of action for injury to these rights survives the death of the union member. Layne v. International Bhd. of Elec. Workers, 418 F. Supp. 964, 966 (D.S.C. 1976); see also E.L. Bowen \& Co. v. American Motors Sales Corp., 153 F. Supp. 42, 45 (E.D. Va. 1957) (wrongful cancellation of automobile franchise injured plaintiff's property rights; cause of action held to survive).

38. See, e.g., Western Auto Supply Co. v. Gamble-Skogmo, Inc., 348 F.2d 736, 741 (8th Cir. 1965) (citing Barnes Coal Corp. v. Retail Coal Merchants Ass'n, 128 F.2d 645, 649 (4th Cir. 1942)). Thus, actions for breach of contract survive, see Ransom v. Brennan, 437 F.2d 513, 520 (5th Cir.), cert. denied, 403 U.S. 904 (1971), and are assignable, El Ranco, Inc. v. First Nat'l Bank, 406 F.2d 1205, 1209 n.4 (9th Cir. 1968), cert. denied, 396 U.S. 875 (1969); Liberty Mut. Ins. Co. v. Davis, 412 F.2d 475, 484 (5th Cir. 1969), even if the contract itself is unassignable by its provisions or because 
Applying these general principles of law to assignments of federal securities claims, courts hold that section $10(\mathrm{~b})$ causes of action ${ }^{39}$ may be assigned. ${ }^{40}$ The more difficult question is whether the sale of the security automatically assigns to the purchaser the seller's cause of action.

\section{B. Effect of a Sale of Property on Rights of Action Incident to the Property.}

1. Intent of the Parties Controls. A mere transfer of property is distinct from an assignment, which is a transfer of rights incident to the property. ${ }^{41}$ In drawing this distinction between the transfer of property and the transfer of rights incident to property, the common law of assignment looks to the intent of the parties in determining the legal effect of a conveyance. ${ }^{42}$ Hence, not every transfer is an assignment, and whether a transfer of certain property is a mere sale of the property or instead an assignment of all rights, title, and interest of the seller in relation to that property depends upon the intent of the parties, ${ }^{43}$ which in turn is a ques-

of its personal nature, Rosecrans v. William S. Lozier, Inc., 142 F.2d 118, 124 (8th Cir. 1944). Contra Cohen v. Webber, 24 Ont. L.R. 171 (1911) (assignment of personal service contract) ("[W] hen the contract has not been or cannot be (as in this case) assigned, it is not competent, when a breach of contract has occurred in respect to which the original party to the contract could sue for damages, for him to assign these damages, or a claim to these damages, so as to enable the assignce to sue in his own name.").

39. Section 16(b) causes of action, likewise, are assignable. Western Auto Supply Co. v. Gamble-Skogmo, Inc., 348 F.2d 736, 741 (8th Cir. 1965).

40. E.g., International Ladies' Garment Workers' Union v. Shields \& Co., 209 F. Supp. 145, 149-50 (S.D.N.Y. 1962) (accepting the reasoning of Judge Forman in Mills v. Sarjem Corp., 133 F. Supp. 753, 761 (D.N.J. 1955)). Courts have reasoned as follows: First, section 28(a), 15 U.S.C. $\S 78(\mathrm{bb})(1982)$, limits recovery under section $10(\mathrm{~b})$ to the plaintiff's actual damage. Scction 78(bb) provides: "no person permitted to maintain a suit for damages under the provisions of [chapter 404 ] shall recover, through satisfaction of judgment in one or more actions, a total amount in excess of his actual damages on account of the act complained of." Consequently, section 10(b) is characterized as remedial rather than penal in nature. Mills, $133 \mathrm{~F}$. Supp. at 761. Second, section 10(b) compensates for injury to property rights incident to the security as opposed to injury personal to the security owner. See, e.g., id. Thus, because section $10(\mathrm{~b})$ is remedial in nature and redresses property injuries, courts hold that section 10(b) claims are assignable:

[T]hose cases holding that section $10(\mathrm{~b})$ claims are freely transferable announce the proper federal rule. Any other rule would be inconsistent with the underlying policy behind that federal statute: the protection of security holders from manipulative or deceptive acts or practices. When such acts or practices have occurred litigation seeking a remedy is often protracted and expensive. Not all victims are so positioned that they can stand either the delay or the expense. Thus they should be able to sell their securities, and the cause of action, in the marketplace at a price which reflects the market's consideration of the value of the claim. Any other rule would compound the injury to the victim by requiring that he await the outcome of a lawsuit before realizing something of what has been taken by the wrongdoer.

Lowry, 707 F.2d at 739-40 (Gibbons, J., dissenting).

41. See supra text accompanying notes 22-23.

42. E.g., Christmas v. Russell, 81 U.S. (14 Wall.) 69,84 (1871).

43. Wood v. Guarantee Trust \& Safe Deposit Co., 128 U.S. 416, 424 (1888). Wood involved a mortgage foreclosure proceeding in which the appellants sought a decree of priority in the distribu- 
tion of fact. ${ }^{44}$

\section{A Contract Law Analogy. A useful example of the distinction} may be seen in the context of contracts to sell warranted personal property, where a cause of action for breach of warranty does not run with the ownership of the property upon resale. ${ }^{45}$ If a seller, $S$, possesses a

tion of the mortgagor's funds held by the clerk of the court. The appellants claimed that they received dishonored coupons of bonds issued by the appellee, City of Joliet Water Works Company, as part payment of the company promoter's debt owed to the appellants, in which case they would be entitled to sue in their own right rather than as assignees of the transferor-promoter. However, the Court held that the parties' intent determined whether the transfer was an assignment; the Court found that the transfer intended was an assignment and that the defenses good against the promoter-that the coupons were past due-were good against the appellant. Id. at 426. See Christmas v. Russell, 81 U.S. (14 Wall.) 69, 84 (1871) (also in context of bill to foreclose mortgage); Li'l Red Barn, Inc. v. Red Barn Sys., 322 F. Supp. 98, 106 (N.D. Ind. 1970) (contract between parties demonstrated intent that assignment have immediate legal effect); Liberty Wall Paper Co. v. Stoner Wall Paper Mfg. Co., 178 N.Y. 219, 221-22, 70 N.E. 501, 502 (1904); $c f$. RESTATEMENT (SECOND) OF CONTRACTS $\S 324$ (1981) ("It is essential to an assignment of a right that the obligee manifest an intention to transfer the right of another person without further action or manifestation of intention by the obligee. The manifestation may be made to the other or to a third person on his behalf and, except as provided by statute or by contract, may be made either orally or by a writing.").

Not only is intent to assign necessary to effect a valid assignment, but a valid assignment must also comply with the other fundamental requisites of contracts in general. In re Bradley, 17 Bankr. 107, 110 (Bankr. M.D. Tenn. 1981); In re Virginia Block Co., 8 Bankr. 616, 618 (Bankr. W.D. Va. 1981). Thus a valid assignment requires mutual assent by proper parties, consideration, and legal subject matter. In re Bradley, 17 Bankr. at 110; In re Virginia Block Co., 8 Bankr. at 618 . Although an assignment requires each of these elements for validity, the assignment need not take any special form. See Hefley v. Jones, 687 F.2d 1383, 1387 (10th Cir. 1982); Erika, Inc. v. Blue Cross \& Blue Shield, 496 F. Supp. 786, 788 (N.D. Ala. 1980); In re Pearl-Wick, 15 Bankr. 143, 146 (Bankr. S.D.N.Y. 1981); Coastal Commercial Corp. v. Samuel Kosoff \& Sons, Inc., 10 A.D.2d 372, 376, 199 N.Y.S.2d 852, 855 (1960); Adams v. Garzillo, 155 Misc. 358, 359, 279 N.Y.S. 398, 399 (N.Y. Mun. Ct. 1935) ("[N]o particular mode or form (in the absence of statute) is necessary to effect a valid assignment, and any acts or words are sufficient which show an intention of transferring or appropriating the owner's interest."). See also In re Pearl-Wick Corp., 26 Bankr. 604, 608 (S.D.N.Y. 1982):

[A]n assignment need not utilize any particular phraseology or form . . .; there must be words which "show an intention of transferring the chose in action to the assignee, when the assignor is divested of all control and right to [the] cause of action and the assignee is entitled to control it and receive its fruits."

(quoting Miller v. Wells Fargo Bank Int'l Corp., 540 F.2d 548, 557 (2d Cir. 1976)).

44. Wood v. Guarantee Trust \& Safe Deposit Co., 128 U.S. 416, 424 (1888).

45. See Hunter-Wilson Distilling Co. v. Foust Distilling Co., 84 F. Supp. 996, 1002 (M.D. Pa. 1949), modified on other grounds, 181 F.2d 543 (3d Cir. 1950), modified on other grounds, 187 F.2d 145 (3d Cir. 1951); Universal C.I.T. Credit Corp. v. State Farm Mut. Auto. Ins. Co., 493 S.W.2d 385, 393 (Mo. Ct. App. 1973); Packard Fabrics, Inc. v. Deering, Milliken \& Co., 94 N.Y.S.2d 671, 673 (N.Y. Sup. Ct. 1949); J.L. Latture Equip. Co. v. Gruendler Patent Crusher \& Pulverizer Co., 133 Or. 421, 430, 289 P. 1067, 1070 (1930); 1 S. Williston, The LAW Governing SALES of Goods $\S 244$, at 645 (rev. ed. 1948); see also Spoo v. Boothe, 453 F.2d 405, 405 (9th Cir. 1971); Superwood Corp. v. Larson-Strang, Inc., 311 F.2d 735, 739 (8th Cir. 1963). Causes of action for breach of other contract terms likewise do not run with the ownership of property. See Wilson $\mathbf{v}$. Haley Live Stock Co., 153 U.S. 39, 46 (1894); Allstate Fin. Corp. v. Zimmerman, 272 F.2d 323, 325 (5th Cir. 1959); Sloss-Sheffield Steel \& Iron Co. v. Wilkes, 231 Ala. 511, 516, 165 So. 764, 768 (1936); Evans v. Savannah \& W. Ry., 90 Ala. 54, 60, 7 So. 758, 760 (1890); Coruelison v. Kornbluth, 
cause of action for breach of warranty against his warrantor, $W$, from whom he originally purchased a good, a subpurchaser from $S$ acquires no right by virtue of the resale to maintain $S$ 's cause of action against $W .{ }^{46}$ $S$ 's cause of action for breach of warranty is not automatically assigned to the subpurchaser as a result of the resale. ${ }^{47}$

One reason that $S$ 's cause of action for breach of warranty does not inure automatically to the subpurchaser's benefit is that the sale of the impaired property does not, of itself, show that the seller intended to assign his claims. ${ }^{48}$ "On the contrary, it may be assumed, that if the original warranty has been broken the original purchaser means to retain whatever right he may have."49 Hence, the seller need not expressly reserve his cause of action when he resells the property. ${ }^{50}$ Instead, courts look to the intent of the parties to a conveyance and thereby maintain the

15 Cal. 3d 590, 607, 542 P.2d 981, 993, 125 Cal. Rptr. 557, 569 (1975) (en banc); Monte Enters. v. Kavanaugh, 62 N.C. App. 541, 543, 303 S.E.2d 194, 196 (1983).

46. See Spoo v. Boothe, 453 F.2d 405, 405 (9th Cir. 1971) (S retains cause of action cven after resale); Hunter-Wilson Distilling Co. v. Foust Distilling Co., 84 F. Supp. 996, 1001 (M.D. Pa. 1949) (stating general rule that benefit of warranty does not inure to subpurchaser), modified on other grounds, 181 F.2d 543 (3d Cir. 1950), modified on other grounds, 187 F.2d 145 (3d Cir. 1951); Packard Fabrics, Inc. v. Deering Milliken \& Co., 94 N.Y.S.2d 671, 673 (N.Y. Sup. Ct. 1949) (S entitled to recover for breach of warranty after resale).

47. Hunter-Wilson Distilling Co. v. Foust Distilling Co., 84 F. Supp. 996, 1002 (M.D. Pa. 1949) ("[T]he mere resale of a warranted article does not give the subpurchaser a right to sue the original seller for damages caused him by defects either in the title or quality of the goods.") (quoting $1 \mathrm{~S}$. WILlistoN, supra note $45, \S 244$, at 645), modified on other grounds, 181 F.2d 543 (3d Cir. 1950), modified on other grounds, 187 F.2d 145 (3d Cir. 1951).

48. Hunter-Wilson Distilling Co. v. Foust Distilling Co., 84 F. Supp. 996, 1002 (M.D. Pa. 1949), modified on other grounds, 181 F.2d 543 (3d Cir. 1950), modified on other grounds, 187 F.2d 145 (3d Cir. 1951); see Sand v. Garford Motor Truck Co., 204 A.D. 70, 72, 198 N.Y.S. 43, 44 (1923); $1 \mathrm{~S}$. WILliston, supra note $45, \S 244$, at 646.

49. Hunter-Wilson Distilling Co. v. Foust Distilling Co., 84 F. Supp. 996, 1002 (M.D. Pa. 1949) (quoting I S. WILLISTON, supra note $45, \S 244$, at 646 ), modified on other grounds, 181 F.2d 543 (3d Cir. 1950), modified on other grounds, 187 F.2d 145 (3d Cir. 1951). A second reason, expressed in Hunter-Wilson Distilling Co., 84 F. Supp. at 1002, why the subpurchaser might not take advantage of his seller's cause of action for breach of warranty without an express assignment, was that the warranty itself was unassignable. Viewing the warranty as a contract of personal indemnity between the original seller and original buyer, the original buyer could not enlarge the scope of the warranty to include the subpurchaser. Id. Today, warranties are assignable. Hunter-Wilson Distilling Co., 181 F.2d at 544-45; Booth v. Scheer, 105 Kan. 643, 646, 185 P. 898, 900 (1919); Scarge v. Lorom, 141 N.Y.S.2d 196, 197-98 (N.Y. Sup. Ct. 1955). Contra Kaiser Aluminum \& Chem. Corp. v. Ingersoll-Rand Co., 519 F. Supp. 60, 73 (S.D. Ga. 1981); thus the second argument why the subpurchaser could not sue in Hunter-Wilson Distilling Co., 84 F. Supp. at 1001, is no longer valid.

Hunter-Wilson Distilling Co. was an action in contract while Lowry sounded in tort. The ground of the cause of action matters in determining whether the cause of action is one that may be assigned. See supra notes 32-38 and accompanying text. The ground of the cause of action makes no difference in determining whether the seller actually assigned his cause of action to the subpurchaser. What inatters is whether the seller intended to part with his cause of action. Wood v. Guarantee Trust \& Safe Deposit Co., 128 U.S. 416, 424 (1888). See supra note 43 and accompanying text.

50. See, e.g., Hunter-Wilson Distilling Co. v. Foust Distilling Co., 84 F. Supp. 996, 1002 (M.D. Pa. 1949), modified on other grounds, 181 F.2d 543 (3d Cir. 1950), modified on other grounds, 187 
distinction between the transfer of property and the transfer of rights by assignment. ${ }^{51}$ The next question to consider, then, is how these general principles of law apply to the circumstances of Lowry.

\section{The Three Resolutions of the Lowry Assignment Question.}

1. Automatic Assignment. The facts in Lowry suggest three alternative resolutions as to the effect of a sale of securities on the seller's section 10(b) claims. The first is the position taken by the Lowry dissenters, Judges Gibbons, Seitz, and Becker, that the sale effects an automatic assignment of the seller's cause of action despite the common law. ${ }^{52}$

Judge Gibbons expressed concern that requiring an express assignment of section 10(b) causes of action would have the practical effect of making such claims unassignable in a faceless market. ${ }^{53}$ Noting that buyers and sellers of securities seldom meet each other because most transfers occur on national stock exchanges or in the over-the-counter market, Judge Gibbons reasoned that a "rule requiring an express assignment of a section 10(b) [claim would be] practically impossible of accomplishment in the real world of the securities markets." 54 Thus, the seller could not realize in the market the incremental value of the cause of action. ${ }^{55}$ Judge Gibbons asserted further, without giving a reason, that the seller would have no incentive to sue the defrauding party, and consequently concluded that wrongdoers would be the primary beneficiaries of a rule requiring an expression of the parties' intent to assign. ${ }^{56}$

Citing different concerns, Chief Judge Seitz, joined by Judge Becker, would have allowed automatic assignment of section 10(b) causes of action, in order to effect congressional intent. ${ }^{57}$ "The primary purpose of section $10(\mathrm{~b})$ and the rules promulgated thereunder is to protect investors from manipulative practices and to deter such practices in the first instance." 58 Chief Judge Seitz reasoned that because fraud is often not

F.2d 145 (3d Cir. 1951) (mere resale of warranted article does not give subpurchaser right to sue original seller for damages caused him by defects in title or quality of article).

51. See supra notes $41-43$ and accompanying text.

52. Lowry, 707 F.2d at 741 (Gibbons, J., dissenting); id. at 746 (Seitz, C.J., joined by Becker, J., dissenting).

53. Id. at 741 .

54. Id. at 741-42.

55. Id. at 742 .

56. Id. For Judge Gibbons's additional criticism of a rule of express assignment, see infra text accompanying notes $76-80$.

57. Lowry, 707 F.2d at 746.

58. Id. In Superintendent of Ins. v. Bankers Life \& Casualty Co., 404 U.S. 6, 13 n.9 (1971), the Supreme Court recognized without further comment that, in furtherance of its deterrence value, section 10(b) implies a private right of action. Under earlier cases, such as Kardon v. National Gypsum Co., 73 F. Supp. 798, 800 (E.D. Pa. 1947), courts reasoned that section 10(b) creates a duty 
discovered until after the investor has sold the security, the investor is unlikely to learn of the fraud because he probably will not follow developments in the status of an investment he no longer owns. ${ }^{59}$ From this, Chief Judge Seitz concluded that an automatic "assignment of a 10(b) claim places the claim with the person most likely to learn of its existence, thus increasing the remedial purposes of the statute and furthering its deterrence goals." 60

2. Implied Intent. The second alternative is that a determination of the parties' intent as inferred from the facts should decide the question whether the sale was also an assignment. The common law rule with respect to assignments is that the intent of the parties controls. ${ }^{61}$ A rule requiring determination of the parties' intent maintains the distinction between the transfer of property and the transfer of rights incident to the property. ${ }^{62}$

3. Express Intent. Rejecting the dissenters' position, Judge Garth proposed the third alternative resolution. He concluded that the parties

of disclosure owed to parties to a transaction, breach of which duty by one party entitles the other to sue for damages. "The liability to account for profits is the correlative liability attendant upon breach of that duty." Id.

Although a private plaintiff, meaning one other than the SEC, may sue for damages, whether or not a private plaintiff may sue for injunctive relief was, at one time, debatable. Loss argues that such a plaintiff should be allowed to bring an action seeking an injunction. $3 \mathrm{~L}$. LOSS, SECuRITIES REGULATION 1796 (2d ed. 1961). He notes that injunctive relief is available to private plaintiffs for violations of section 14(a) of the Securities Exchange Act of 1934, 15 U.S.C. $\S 78 \mathrm{n}$ (a) (1982) (fraudulent proxy statements), and of section 12(2) of the Securities Act of 1933, 15 U.S.C. $\S 771(2)$ (1982) (fraudulent registration statement or prospectus), and concludes that "there is no apparent reason to suppose that a private plaintiff, once the Kardon doctrine gets him into court, should not be entitled to the same relief." 3 L. Loss, supra, at 1796. However, as Loss points out, at least one district court has refused to grant a private plaintiff injunctive relief. See Goldsmith v. Western \& S. Life Ins. Co., 5 SEC Jud. Dec. $795-97$ (N.D. Ohio 1948) (oral opinion). Nevertheless, since the time of Loss's writing and the Goldsmith case, several federal courts of appeals have made clear, consistent with Loss's view, that private plaintiffs may sue to enjoin future violations of section 10(b). See Herpich v. Wallace, 430 F.2d 792, 813 (5th Cir. 1970) (injunction sought to prevent merger in violation of Rule 10b-5); Kahan v. Rosentiel, 424 F.2d 161, $169-73$ (3d Cir.), cert. denied, 398 U.S. 950 (1970); Britt v. Cyril Bath Co., 417 F.2d 433, 436 (6th Cir. 1969) ("it is . . . clear that the requirements of causation and reliance are not so strong in a private action to enjoin" acts under section 10(b)); Mutual Shares Corp. v. Genesco, Inc., 384 F.2d 540, 546-47 (2d Cir. 1967) (injunctive relief granted to private party even though plaintiff failed to secure monetary damages).

59. Lowry, 707 F.2d at 746.

60. Id. Judge Gibbons and Chief Judge Seitz may reach the correct result when the fraud is not public information at the time of the resale and no one subsequently prosecutes a claim based on the fraud. However, it is unlikely that another holder would not step forward to prosecute a class action, and in the process, notify the seller of his claim. In any case, the fraud in Lowry was public information at the time of the purchase.

61. See supra note 43 and accompanying text.

62. See supra notes $22-23,41-51$ and accompanying text. 
must express their intent to assign. ${ }^{63}$ In reaching this conclusion, Judge Garth relied on Independent Investor Protective League v. Saunders, ${ }^{64}$ in which Chief Judge Lord had agreed that section 10(b) claims may be conveyed by express assignment, but flatly rejected the "extraordinary" proposition that the claims run with the security, reasoning that the securities laws were not meant to protect subsequent purchasers who had not been defrauded. ${ }^{65}$ Automatic assignment, he argued, would create windfalls for those subsequent takers who by good fortune or investment skill had come into a security once owned by a defrauded party. The section $10(\mathrm{~b})$ claims "do not attach for all eternity to the security itself, to pass forever from the person who has been harmed to be asserted by others who have not." 66

\section{Automatic Assignment Versus the Common LAw: A Weak Case for Change}

The current rule of express assignment ${ }^{67}$ is consistent with the general common law of assignments im looking to the parties' intent. ${ }^{68}$ There is no reason to suppose that one who sells a security intends thereby to convey whatever rights he may have against one who has defrauded him. Moreover, a rule of express assignment is consistent with the purchase-or-sale rule of Blue Chip Stamps v. Manor Drug Stores, ${ }^{69}$ and avoids awarding windfalls to uninjured security holders. ${ }^{70}$

63. Lowry, 707 F.2d at 729.

64. 64 F.R.D. 564 (E.D. Pa. 1974).

65. Id. at 572 .

66. Id.

67. Rose v. Arkansas Valley Envtl. \& Util. Auth., 562 F. Supp. 1180 (W.D. Mo. 1983), decided shortly before Lowry, relied on Independent Investor Protective League v. Saunders, 64 F.R.D. 564, 572 (E.D. Pa. 1974), in rejecting the contention that by virtue of their ownership of the securities, donees or legatees acceded to the ownership of their predecessors' causes of action in the absence of an express assignment. "[T] he cause of action itself is entirely separate and distinct from the security which gave rise to it, and does not automatically follow the ownership of that security." Rose, 562 F. Supp. at 1189 (emphasis omitted). In In re Penn Cent. Transp. Co., 337 F. Supp. 791, 794 (E.D. Pa. 1972), the district court required an express assignment of the debtor's cause of action as a condition of the sale of the debtor's assets. Implicitly, at least, if the assignment were other than express, no assignment would be effected. See id. at 794.

Adoption of the automatic assignment theory might change the result in Kerrigan v. Merrill Lynch, Pierce, Fenner \& Smith, Inc., 450 F. Supp. 639, 647 (S.D.N.Y. 1978) (widow of purchaser lacks standing to assert Rule 10b-5 claim), and Lincoln Nat'l Bank v. Lampe, 414 F. Supp. 1270, 1280-81 (N.D. IIl. 1976) (trust beneficiary lacks standing to assert Rule 10b-5 claim).

68. See supra notes 41-51 and accompanying text; infra notes 94-99 and accompanying text.

69. 421 U.S. 723 (1975); see infra notes 100-10 and accompanying text.

70. See infra notes $100-04$ and accompanying text. 


\section{A. The "Unassignability" Argument.}

A rule requiring an expression of the parties' intent would not make section 10(b) claims unassignable for all practical purposes as Judge Gibbons feared. ${ }^{71}$ Even in a faceless market, buyers can buy and sellers can sell without meeting one another to agree on the terms; buyers and sellers agree on price and quantity routinely through intermediary brokers. Whether the seller also transfers his cause of action to the buyer is but another term of the contract, like price and quantity, upon which the parties can agree through their intermediary. ${ }^{72}$ Thus, a rule of express assignments is practicable, and sellers can realize the incremental value of their causes of action in the market.

\section{B. Incentive to Pursue the Claim.}

Judge Gibbons also asserted, without elaboration, that once "the sale has occurred the seller will have almost no incentive to pursue the claim." 73 This unsupported assertion is inconsistent with his prior statement that, because express assignment of a cause of action would be "practically impossible" in existing securities markets, a "rule requiring an express assignment of a section 10(b) [claim] or any other federally based claim connected with it . . . would have the inevitable effect that the seller cannot realize any increment in the market based on public knowledge of its existence."74 That very inability to realize the incremental value of the cause of action would provide the incentive to pursue the claim.

On the other hand, if the seller can realize the incremental value of the cause of action in the market under a rule of express assignment, ${ }^{75}$ buyers will offer a lower price when buying from one who declines to assign his cause of action. If the seller does not assign, he realizes his loss caused by the underlying fraud and has incentive to pursue the claim. Alternatively, buyers will offer a higher price to sellers who are willing to assign their causes of action. The buyer who pays a higher price and receives an express assignment of the seller's cause of action will also have incentive to pursue the seller's claim.

Thus, establishing a rule requiring express assignment creates a market for the cause of action and ensures its enforcement by providing the owner of the cause of action with incentive to pursue it. Of course, a rule

71. See Lowry, 707 F.2d at 741.

72. Other negotiable terms include date and place of delivery, form of payment, and timing of dividends.

73. Lowry, 707 F.2d at 742.

74. Id. at 741-42.

75. See supra text accompanying notes 71-72. 
allowing automatic assignment would also create a market for the cause of action and provide incentives to pursue the cause of action. The point is that either rule has the effect of creating a market and providing incentives with the result of effectuating the congressional purpose behind section $10(\mathrm{~b})$.

\section{C. "Overriding Federal Concerns."}

1. The "Lack of Uniformity" Argument. Citing "overriding federal concerns," Judge Gibbons further criticized the rule of express assignment on the ground that it would produce a lack of uniformity between state and federal law and would lead to double liability. ${ }^{76}$ Federal courts have exclusive jurisdiction over section 10(b) actions. ${ }^{77}$ As a practical matter, state common law fraud claims need to be filed with the federal action as pendent claims. ${ }^{78}$ Many states provide by statute that transferees of securities take the claims of their transferors unless expressly reserved in writing. ${ }^{79}$ Thus, state law on the assignment question would be contrary to a federal rule of express assignment. Nonuniform rules-state law providing for automatic assignment, federal law for express assignment-would not vest ownership of the state and federal claims in the same parties. Judge Gibbons argued that this lack of uniformity would make the settlement of section 10(b) class actions more difficult, that defendants might face double liability, and that administration of a remedy would be difficult for district courts. ${ }^{80}$

\section{Restitutionary Decrees in the Class Action Litigation Context.} District courts, however, can approach class action settlements under nonuniform rules of assignment in much the same way they approach the administration of a decree of restitution in a class action. In litigation under the securities laws courts have broad remedial powers, ${ }^{81}$ one of which is to grant restitution to the successful plaintiff-whether a private litigant ${ }^{82}$ or the SEC. ${ }^{83}$ The court may order the proceeds of the decree ${ }^{84}$ placed in trust as a common fund from which all claimants may draw for

76. Lowry, 707 F.2d at 743 .

77. Securities Exchange Act of 1934, $\$ 27,15$ U.S.C. $\S 78 \mathrm{aa}$ (1982).

78. Lowry, 707 F.2d at 743.

79. See, e.g., N.Y. U.C.C. $\S 8-301(1)$ (McKinney Supp. 1984) ("Upon transfer of a security to a purchaser (Section 8-313) the purchaser acquires the rights in the security which his transferor had or had actual authority to convey . . . .")

80. Lowry, 707 F.2d at 743.

81. See Mills v. Electric Auto-Lite Co., 396 U.S. 375, 386-89 (1970); J. I. Case Co. v. Borak, 377 U.S. $426,433-34$ (1964).

82. E.g., Mills v. Electric Auto-Lite Co., 396 U.S. 375, 391 (1970).

83. SEC v. Manor Nursing Centers, Inc., 458 F.2d 1082, 1103-04 (2d Cir. 1972); SEC v. Texas Gulf Sulphur Co., 446 F.2d 1301, 1308 (2d Cir. 1971) (citing Mills v. Electric Auto-Lite Co., 396 
a limited time or thereafter be barred from recovery. ${ }^{85}$ At the end of the life of the trust, any remaining funds will pass to the issuer whose security was the subject of the section 10(b) suit. ${ }^{86}$ This approach helps to deter securities law violations, compensates those parties who step forward to participate in the award, and, by limiting damages to disgorgement, prevents holding the defendant liable twice. ${ }^{87}$

3. Class Action Settlements and Double Liability Under a Rule of Express Assignment. District courts could employ much the same approach in cases in which, as a result of nonuniform rules of assignment, one class of plaintiffs holds section 10(b) claims and another class holds state common law fraud claims. The defendant could agree with the plaintiff class to disgorge the ill-gotten gains into a common fund held in trust for payment to those members of the class who step forward and establish their right to recover during a limited period of time and in the order in which they file their claims. To conclude that the federal and state law governing the transfer of securities causes of action uniformly must favor automatic assignment thus requires more than an assertion that settlements otherwise will be more difficult to accomplish. The conclusion is particularly unwarranted when the burden on courts of having a state rule of automatic assignment and a federal rule of express assignment is no greater than that encountered in court-ordered remedial con-

U.S. 375, 391 (1970)); see, e.g., SEC v. Scott, 565 F. Supp. 1513, 1536 (S.D.N.Y. 1983) (listing the range of relief available to SEC for section 10(b) violations).

84. For a discussion of what the defendant must disgorge, see SEC v. Manor Nursing Centers, Inc., 458 F.2d 1082, 1104 (2d Cir. 1972) (defendants must disgorge proceeds but not profits and income earned on such proceeds).

85. Id. at 1103; SEC v. Texas Gulf Sulphur Co., 446 F.2d 1301, 1307 (2d Cir. 1971). See generally R. Jennings \& R. Buxbaum, Corporations: Cases and Materials 608 (5th ed. 1979); Note, A Comparison of Insider Liability under Diamond v. Oreamuno and Federal Securities Law, 11 B.C. INDUS. \& CoM. L. REv. 499, 514-15 (1970).

86. SEC v. Texas Gulf Sulphur Co., 446 F.2d 1301, 1307 (2d Cir. 1971), affg 312 F. Supp. 77 (S.D.N.Y. 1970). In Texas Gulf Sulphur, the Court of Appeals for the Second Circuit upheld the lower court's order to the defendants-corporate directors-to disgorge profits they earned trading on nonpublic information in violation of section 10(b) of the Securities Exchangc Act of 1934, 15 U.S.C. § 78j(b) (1982), and Rule 10b-5, 17 C.F.R. § 240.10b-5 (1984):

The payments are to be held in escrow in an interest-bearing account for a period of five years, subject to disposition in such manner as the court might direct upon application by the SEC or other interested person, or on the court's own motion. At the end of five years any money remaining undisposed of would become the property of [thc defendant-appellant corporation, Texas Gulf Sulphur Companyl. To protect the [defendant-appellant directors] against double liability, any private judgments against these [directors] arising out of the events of this case are to be paid from this fund.

Texas Gulf Sulphur, 446 F.2d at 1307. See also SEC v. Blavin, 557 F. Supp. 1304, 1316 (E.D. Mich. 1983) (court ordered defendants to disgorge ill-gotten gains and instructed SEC to formulate plan for disposition of funds so disgorged under which defendant's victims would be compensated wherever possible).

87. See SEC v. Texas Gulf Sulphur Co., 446 F.2d 1301, 1307-08 (2d Cir. 1971). 
texts under the securities laws. ${ }^{88}$

\section{Maximum Deterrence Value.}

Chief Judge Seitz also sought to effect congressional intent in reasoning that, if investors sell before they discover their causes of action, then an automatic assignment places the section 10(b) claim "with the person most likely to learn of its existence." 89 Thus, an automatic assignment rule would better realize the congressional purpose of enforcing the securities laws than would a rule requiring express assignments. ${ }^{90}$

Chief Judge Seitz, however, based his conclusion on an analysis of the situation in which the seller is unaware of the fraud at the time of the sale. In Lowry, the fraud had become public knowledge.91 His analysis assumed that all investors sell before they learn of the cause of action and that they do not subsequently discover it. ${ }^{92}$ Yet the remedial and deterrent purposes of the statute require but one investor who is willing to sue; almost never will all defrauded investors sell before the fraud becomes public knowledge. Under a rule of express assignment, either sellers who do not assign their rights of action or purchasers who have received express assignments from their predecessors in title can sue.

Thus, a rule requiring an express assignment effectuates the purposes of section $10(\mathrm{~b})$ at least as well as one providing for automatic assignments. A firm conclusion that one rule better implements congressional intent cannot be based on the dubious claim that the buyer is more likely to learn of the cause of action than the seller. Other considerations must be addressed to resolve the issue. 93

88. The suggested approach would preclude double liability by limiting the amount of damages to restitution. For that matter, however, there "is no absolute rule of [securities] law precluding double liability." Lowry v. Baltimore \& O.R.R., 707 F.2d 721, 731 n.16 (3d Cir. 1983) (en banc) (Garth, J., concurring) (quoting Loss, supra note 58, at 1474 (bracketed material supplied by Garth, J.)). Even if this suggested approach proves to be overly burdensome on district courts, to avoid the double liability resulting from non-uniform rules, federal law could be held to preempt conflicting state law. Furthermore, pendent jurisdiction exists not as a means of determining substantive federal securities law, but rather as a matter of convenience.

89. Lowry, 707 F.2d at 746.

90. Id.

91. Unlike the case Chief Judge Seitz analyzed, Lowry involved a cause of action known to the seller, as well as to the buyer. The two cases differ significantly and, indeed, may call for contrary results. Thus, the Lowry facts did not call for an analysis of the case of fraud unknown to the public. Perhaps, in such a case, a rule of automatic assignment would better effect congressional intent. However, the subpurchaser who takes before the cause of action becomes public information may have a section 10(b) cause of action in his own right, and there would then be no need to consider the assignment question. A further exploration of the nonpublic fraud case, however, is beyond the scope of this note.

92. Lowry, 707 F.2d at 746.

93. See infra notes $94-110$ and accompanying text. 


\section{A Rule of EXPRESS Assignment}

A. Consistency with the Common Law of Assignment.

As discussed above, ${ }^{94}$ rights of action for breach of warranty are not automatically assigned upon resale of the warranted property. ${ }^{95}$ Again, the reason for the rule is that by selling the property the seller probably does not intend to part with his cause of action for breach of warranty against his seller. ${ }^{96}$ The intent of the parties determines whether the sale is also an assignment of the seller's cause of action. ${ }^{97}$

The rule with respect to assignment of rights of action under the federal securities laws should be the same as the rule with respect to assignment of rights of action for breach of warranty. There is no more reason to suppose that the sale of a security indicates that the seller intended to part with his federal securities law claims than there is to suppose that the sale of warranted property shows that the seller intended to part with his cause of action for breach of warranty. In holding that a cause of action is automatically assigned upon sale of a security, Chief Judge Seitz and Judges Gibbons and Becker failed to consider the intent of the parties, ${ }^{98}$ contrary to the general law of assignments. Their opinions overlook the distinction between the transfer of property and the transfer of rights incident to property. ${ }^{99}$

\section{B. Consistency with the Purchase-or-Sale Rule.}

A further effect of a rule favoring automatic assignment is that all subsequent purchasers may assert their predecessors' causes of action; the causes of action run with the ownership of the securities forever. As a consequence, if the public suddenly becomes aware of a section $10(\mathrm{~b})$ clain and the inarket adjusts itself to the new-found value of the security, subsequent purchasers who have not been injured by the fraud that gave rise to their assignors' causes of action are entitled, nevertheless, to recover as assignees. Yet the so-called "purchase or sale" rule contemplated the protection only of defrauded purchasers and sellers. ${ }^{100}$

94. See supra notes $45-51$ and accompanying text.

95. Hunter-Wilson Distilling Co. v. Foust Distilling Co., 84 F. Supp. 996, 1002 (M.D. Pa. 1949), modified on other grounds, 181 F.2d 543 (3d Cir. 1950), modified on other grounds, 187 F.2d 145 (3d Cir. 1951).

96. $I d$.

97. Wood v. Guarantee Trust \& Safe Deposit Co., 128 U.S. 416, 424 (1888).

98. Lowry, 707 F.2d at 741 (Gibbons, J., dissenting); id. at 746 (Seitz, C.J., joined by Becker, J., dissenting).

99. See supra notes $41-43$ and accompanying text.

100. See Blue Chip Stamps v. Manor Drug Stores, 421 U.S. 723, 754-55 (1975); Birnbaum v. Newport Steel Corp., 193 F.2d 461, 463-64 (2d Cir.) (Hand, Augustus N., J.), cert. denied, 343 U.S. 956 (1956). Blue Chip Stamps interpreted the "in connection with the purchase or sale" language of 
Section 10(b) "was directed solely at that type of misrepresentation or fraudulent practice usually associated with the sale or purchase of securities ... and . . Rule [10b-5] extended protection only to the defrauded purchaser or seller."101 Section 10(b) and Rule 10b-5 ${ }^{102}$ were not intended to protect purchasers or sellers who have not been defrauded. ${ }^{103}$ Subsequent purchasers who were not defrauded, but who assert the causes of action of their predecessors merely by virtue of owning the securities, are not in the class of persons Congress sought to protect in enacting section $10(\mathrm{~b})$. Permitting section $10(\mathrm{~b})$ claims to run with the ownership of the securities expands the class of plaintiffs far beyond that which Congress contemplated. ${ }^{104}$

An express assignment of a section 10(b) claim is consistent with the purchase-or-sale rule. Although a subsequent purchaser is not within the class of persons Congress sought to protect in enacting section 10(b), an express assignee of a seller's section 10(b) cause of action "steps into the shoes of his assignor" and thereby meets the purchase-or-sale requirement. ${ }^{105}$ But if all subsequent purchasers are allowed to assert their predecessors' causes of action by automatic assignment, meeting the purchase-or-sale rule through their assignors, the class of plaintiffs will be vastly expanded to include any subpurchaser regardless of whether that subpurchaser was defrauded, unless the clain was expressly reserved. Although Congress arguably did not intend to protect express

section 10(b), see supra note 2, to mean literally that only actual purchasers and sellers could sue thereunder. Blue Chip Stamps, 421 U.S. at 754-55.

101. Birnbaum v. Newport Steel Corp., 193 F.2d 461, 464 (2d Cir. 1952).

102. 17 C.F.R. § 240.10b-5 (1984).

103. Blue Chip Stamps v. Manor Drug Stores, 421 U.S. 723, 731, 733, 736 n.8 (1975).

104. The language "expands the class of plaintiffs" does not mean that the aggregate number of causes of action in existence increases. This note uses the term here in the same sense that the Supreme Court did in Blue Chip Stamps when it adopted the Birnbaum approach to hold "that the plaintiff class for purposes of $\S 10(\mathrm{~b})$ and Rule 10b-5 private damage actions is limited to purchasers and sellers of securities." Id. at 731-32. The Blue Chip Stamps Court stated: "It would indeed be anomalous to impute to Congress an intention to expand the plaintiff class for a judicially implied cause of action beyond the bounds it delineated for comparable express causes of action." Id. at 736. Because subsequent purchasers are outside the class of actual purchasers or sellers affected by a fraud, to afford them a cause of action through automatic assignment would "expand the class of plaintiff" even though the number of choses in action remains constant.

This interpretation can be squared with an approach that requires intentional assignment of a chose in action, such as where the cause of action is expressly assigned. Under a regime of automatic assignments, the original purchaser, the object of congressional protection, may receive nothing while the subsequent purchaser enjoys a windfall. On the other hand, an intentional assignment protects the original purchaser's interests. That party either receives value or makes a gift; no similar problem of class expansion is created when the subsequent purchaser asserts the right. See infra notes 105-07 and accompanying text.

105. $I d$. 
assignees, ${ }^{106}$ because they have not themselves been defrauded, courts nevertheless have long permitted express assignees to sue. ${ }^{107}$

Following the parties' intent limits the potential class of plaintiffs and satisfies the purchase-or-sale rule. ${ }^{108}$ If the parties' intent determines who receives redress for the wrong, the value of the cause of action will be figured into the transaction, and the subsequent purchaser is less likely to realize a windfall. Conversely, if the assignment is automatic, the subsequent purchaser might realize a windfall, and the party who is actually injured may be deprived of compensation he could have received if the section 10(b) cause of action had been public information at the time of the resale. ${ }^{109}$ Section 10(b) was not intended to award a windfall to those who are neither purchasers nor sellers. ${ }^{110}$ Because subpurchasers are less likely to realize windfalls where the intent of the parties controls than where the assignment is automatic, a rule that looks to the parties' intent is superior to one of automatic assignment to resolve the issue whether a section 10(b) cause of action has run with the security.

106. A rule of express assignment protects the express assignor to the extent that the express assignee compensates him for the assignment, whereas a rule of automatic assignment deprives the seller of compensation absent a reservation of the cause of action. See supra note 104.

107. See, e.g., International Ladies' Garment Workers' Union v. Shields \& Co., 209 F. Supp. 145, 149 (S.D.N.Y. 1962). Sanctioning express assignment does not necessarily mean that one who holds a cause of action could assign his right to one who does not also take a legal interest in the underlying property. To sue on the cause expressly assigned, the assignment must be coupled with a legal interest. See Wogahn v. Stevens, 236 Wis. 122, 128, 294 N.W. 503, 504 (1940) (action of a remedial or contractual, rather than personal, nature will survive death of holder). But see Continental Assurance Co. v. American Bankshares Corp., 483 F. Supp. 175, 178 (E.D. Wis. 1980) (criticizing Wogahn).

108. Whether an assignment implied from the facts is consistent with the purchase-or-sale rule expressed in Blue Chip Stamps relates to the question whether section 10(b) causes of action are assignable in the first instance. See supra notes $39-40$ and accompanying text. If the assignee does not meet the purchase or sale requirement, the cause of action is effectively unassignable since the assignment would not benefit the subpurchaser. Yet, section $10(\mathrm{~b})$ claims are undoubtedly assignable. See supra notes $39-40$ and accompanying text. Courts do not hesitate to allow the express or implied assignee to pursue his assignor's section 10(b) claim. See, e.g., International Ladies' Garment Workers' Union v. Shields \& Co., 209 F. Supp. 145, 149-50 (S.D.N.Y. 1962). As an express or implied assignee of his seller's right of action, the subpurchaser may assert all defenses that his assignor could have asserted. See $3 \mathrm{~S}$. Williston, A Treatise on the LaW of Contracts $\S 432 \mathrm{~A}$ (3d ed. 1960); cf. Smith v. Bear, 237 F.2d 79, 81 (2d Cir. 1956) (plaintiff-assignee of section 10(b) claim and other claims took subject to defenses assertable against his assignor); Gluck v. Amicus, Inc., 487 F. Supp. 608, 612 (S.D.N.Y. 1980) (assignees of section 10(b) actions took subject to defenses assertable against their assignors); Carpenter v. Hall, 311 F. Supp. 1099, 1113 (S.D. Tex. 1970) (trustee in bankruptcy had standing to pursue debtor's section lO(b) claims). Thus, if the assignor meets the purchase-or-sale rule, the assignee "steps into the shoes of his assignor" and satisfies the purchase-or-sale requirement.

109. See supra notes 104, 106.

110. See Blue Chip Stamps v. Manor Drug Stores, 421 U.S. 723, 731-33 (1975) (upholding Birnbaum doctrine). 


\section{INFERring INTENT: EXPRESS AsSignMent AS A Practical NECESSITY}

A. The Facts Available.

Intent to assign may be express or implied. ${ }^{111}$ However, in a faceless market, whether an assignment was intended is almost impossible to determine in the absence of an expression of the parties' intent, and thus the second alternative-inferring intent-should be rejected. The only objective evidence of the parties' intent ${ }^{112}$ is the price paid for the security by the subpurchaser. Yet the price conceals a host of variables and is subject to multiple interpretations. ${ }^{113}$ Price is therefore not a reliable indication of the parties' intent. In a faceless market, nothing short of an expression by the parties will support a conclusion as to their intent.

\section{B. Class Action Complications.}

Maintaining a class action on an implied assignment of a claim presents difficulties in addition to those encountered in drawing an inference of the parties' intent from the available facts. Implied intent to assign is similar to the question of reliance in common law fraud. A class action alleging fraud, in which reliance on misstatements of material facts is a necessary element, presents special problems because the element of reliance on the defendant's misrepresentations may differ for each allegedly defrauded plaintiff. ${ }^{114}$ Likewise, the intent of the seller of the security to assign his cause of action may differ from one seller to the next. Where there is no expression of the parties' intent, so that intent must be inferred from the facts, the class action device is of little assistance. ${ }^{115}$ Therefore, requiring express assignments facilitates class actions

111. See Ketchum v. Duncan, 96 U.S. 659, 662 (1877).

112. If the parties were asked what legal effect they intended, one would predict a self-serving response; the buyer would say "assignment" while the seller would say "sale."

113. For example, in Lowry, 707 F.2d at 729 n.10, the market price of the convertible debentures showed little change after the fraud was announced. The market price the plaintiffs paid could mean that the seller intended to transfer his cause of action because the purchasers paid a fair price for it, or that the cause of action was worthless because the parties deemed the possibility of recovery as minimal. Thus, the price could be interpreted in at least two ways, and whether the seller intended to assign the causes of action could not be inferred from the price the plaintiffs paid.

114. See In re Hotel Tel. Charges, 500 F.2d 86, 89 (9th Cir. 1974); Avila S. Condominium Ass'n v. Kappa Corp., 347 So. 2d 599, 608-09 (Fla. 1977); cf. Grimes v. Pitney Bowes Inc., 100 F.R.D. 265, 270 (N.D. Ga. 1983) (employment discrimination context).

115. Suits must be brought individually, and each plaintiff must plead the facts of his assignment. See FED. R. CIV. P. 23(2), (3) (to sue as a class there must be common questions of law or fact, and typicality of claims or defenses); Amalgamated Workers Union v. Hess Oil Virgin Islands Corp., 478 F.2d 540, 543 (3d Cir. 1973); see also American Pipe \& Constr. Co. v. Utah, 414 U.S. 538, 550-52 (1974) ("A federal class action is . . . a truly representative suit designed to avoid, rather than encourage, unnecessary filing of repetitious papers and motions"); Hansberry v. Lee, 311 
and promotes the use of this valuable tool in the enforcement of securities laws.

\section{CONCLUSION}

A bright-line solution to the assignment issue raised in Lowry is desirable, as demonstrated by the difficulties in inferring the parties' intent from the facts and in using the class action device. The dissenters in Lowry elected a bright-line interpretation of section 10(b) that would allow claims to run automatically upon sale of the security.

This note has argued that the dissenters' interpretation of section 10 (b) is flawed, in that (1) assignment of claims is not impracticable in today's securities markets, (2) sellers who do not convey their claims still have an incentive to pursue them, (3) "overriding federal concerns" do not necessarily mitigate in favor of a rule of automatic assignment, and (4) a rule of express assignment deters fraud as well as one of automatic assignment. Requiring an expression of the parties' intent is consistent with the law of assignment both in accounting for the parties' intent and in maintaining the distinction between a sale and an assignment. The express assignee also meets the purchase-or-sale requirement via his assignor. Thus the expressed intent of the parties should control the issue of whether the subpurchaser may assert his seller's section 10(b) cause of action.

David C. Profilet

U.S. 32, 41 (1940) (impracticability of joinder necessitates class action device); Suchem, Inc. v. Central Aguirre Sugar Co., 52 F.R.D. 348, 353 (D.P.R. 1971) (class action permits court to adjudicate rights of many persons "by one common final judgment). Absent an express assignment, many trials would be called for and subsequent plaintiffs could not collaterally estop the defendant from relitigating the assignment question.

This is not to say that a purchaser might not successfully argue that he received an assignment of his seller's cause of action by implication. Indeed, the Lowry plaintiffs could have presented a cogent argument that they implicitly received their predecessors' causes of action; the plaintiffs paid a price that arguably refiected the value of the cause of action, they were aware of the fraud at the time of their purchase, and they intended at that time to maintain their sellers' causes of action. Lowry, 707 F.2d at 725 n.5. Inquiry concerning the intent of the plaintiffs' sellers might have proved helpful. 